\title{
Peningkatan Kreativitas Siswa Kelas IV SD Melalui Pembelajaran Tematik- Integratif dengan Pendekatan Open-Ended
}

\author{
Resna Maulia Ayu Bernadi \\ SD Negeri 1 Prapaglor. Klimparan RT. 1/3, Kec. Pituruh, Purworejo, 54263, Indonesia \\ Korespondensi Penulis. Email: resnahoed@yahoo.co.id \\ Received: 7 January 2016; Revised:10 June 2016; Accepted: 3 October 2016
}

\begin{abstract}
Abstrak
Penelitian ini bertujuan untuk meningkatkan kreativitas peserta didik kelas IV SD Negeri I Prapaglor, Pituruh, Purworejo melalui pembelajaran tematik integratif dengan menerapkan pendekatan open ended. Penelitian ini merupakan penelitian tindakan kelas yang dilaksanakan dalam tiga siklus. Hasil penelitian menunjukkan bahwa setelah diterapkan pendekatan open ended kreativitas peserta didik mengalami peningkatan. Peserta didik yang telah mencapai kriteria kreatif atau sangat kreatif sebanyak 12 anak (75\%). Hasil tes kreativitas peserta didik mengalami peningkatan dari siklus I ke siklus II dan dari siklus II ke siklus III. Hasil tes kreativitas peserta didik yang mencapai kategori kreatif dan sangat kreatif pada siklus I sebesar 0\%, siklus II 31,25\%, dan siklus III $75 \%$.
\end{abstract}

Kata Kunci: kreativitas, tematik integratif, pendekatan open ended

\section{Enhancing Creativity of Class IV SD Through Thematic Integrated Learning with Open-Ended Approach}

\begin{abstract}
This research aims to improve the creativity of the fourth grade students of Prapaglor 1 State Elementary School, Pituruh, Purworejo through thematic integrative teaching with the open ended approach. This research is a classroom action research conducted in three cycles. The result of the research shows that there is an improvement on the students after the open ended approach was implemented in the teaching and learning process. There are 12 students having high creativity (75\%). There is enhancement on the students' creativity from Cycle I to Cycle II and from Cycle II to Cycle III. The result of the creativity test of the students having high creativity (very creative) in Cycle I is $0 \%$, Cycle II was $31.25 \%$, and Cycle III is $75 \%$.
\end{abstract}

Keywords: creativity, thematic integrative, open ended approach

How to Cite: Bernadi, R. (2017). Peningkatan kreativitas siswa kelas IV SD melalui pembelajaran tematik integratif dengan pendekatan open-ended. Jurnal Prima Edukasia, 5(1), 91-101. doi:http://dx.doi.org/10.21831/jpe.v5i1.7783

Permalink/DOI: http://dx.doi.org/10.21831/jpe.v5i1.7783 


\section{Jurnal Prima Edukasia, 5 (1), January 2017 - 92}

Resna Maulia Ayu Bernadi

\section{Pendahuluan}

Tujuan pendidikan nasional menurut Undang-Undang Sistem Pendidikan Nasional Nomor 20 Tahun 2003 tentang Sistem Pendidikan Nasional adalah mengembangkan potensi peserta didik agar menjadi manusia yang beriman dan bertaqwa kepada Tuhan Yang Maha Esa, berakhlak mulia, sehat, berilmu, cakap, kreatif, mandiri, dan menjadi warga negara yang demokratis serta bertanggung jawab. Untuk mewujudkan tujuan tersebut perlu dikembangkan kecakapan dalam proses pendidikan, diantaranya adalah peningkatan kreativitas peserta didik.

Kreativitas menurut Hurlock (2000, p.4) adalah "kemampuan seseorang untuk menghasilkan komposisi, produk, atau gagasan apa saja yang pada dasarnya baru". Kemampuan menciptakan sesuatu yang baru sudah harus dimulai ketika peserta didik berada pada jenjang Sekolah Dasar (SD). Hal ini karena SD merupakan jenjang pendidikan formal yang paling awal. Kurikulum baru yang mulai diterapkan pada tahun pelajaran 2014/2015 adalah Kurikulum 2013. Permendikbud Nomor 65 tahun 2013 Tentang Standar Proses Pendidikan Dasar dan Menengah disebutkan bahwa prinsip pembelajaran yang digunakan pada Kurikulum 2013 adalah pembelajaran terpadu dengan pendekatan tematik integratif.

Pembelajaran tematik didefinisikan sebagai proses integrasi dan menghubungkan beberapa elemen kegiatan kurikulum dari berbagai aspek dan topik atau subjek. Interaksi ini melibatkan antara guru, siswa dan lingkungan kelas. Unsur-unsur penting dalam pembelajaran tematik adalah tema, eksplorasi guru, integrasi tema dengan kurikulum dan pusat belajar, serta membangun atau menjaga semangat dan antusiasme siswa (Nurmin \& Kartowagiran, 2013, p.186). Pembelajaran tematik integratif merupakan pendekatan pembelajaran yang mengaitkan beberapa aspek antar mata pelajaran. Mata pelajaran di SD dikelompokkan menjadi dua bagian. Kelompok pertama adalah kelompok mata pelajaran yang berorientasi pada aspek kognitif dan afektif adalah Pendidikan Agama dan Budi Pekerti, Pendidikan Pancasila dan Kewarganegraan (PPKn), Bahasa Indonesia, Matematika, IPA, dan IPS. Kelompok kedua adalah kelompok mata pelajaran yang berorientasi pada aspek afektif dan psikomotor. Mata pelajaran yang masuk di dalamnya adalah Pendidikan Jasmani, Seni Budaya dan Prakarya, serta Muatan Lokal.

Salah satu mata pelajaran yang diajarkan di SD adalah matematika. Menurut Suherman, et.al (2003, p.25) matematika sebagai ratu atau ibunya ilmu dimaksudkan bahwa matematika adalah sebagai sumber dari ilmu yang lain. Artinya adalah banyak ilmu-ilmu yang penemuan dan pengembangannya bergantung dari matematika. Begitu pentingnya matematika sehingga pembelajaran matematika diberikan pada semua jenjang pendidikan mulai dari SD hingga perguruan tinggi (PT). Tujuan pembelajaran matematika di sekolah dasar menurut Depdiknas (Susanto, 2013, p.189) yaitu (1) melakukan operasi hitung penjumlahan, pengurangan, perkalian, pembagian beserta campurannya, termasuk yang melibatkan pecahan, (2) menentukan sifat dan unsur berbagai bangun datar dan bangun ruang sederhana, termasuk penggunaan sudut, keliling, luas, dan volume, (3) menentukan sifat simetri, kesebangunan, dan sistem koordinat, (4) menggunakan pengukuran, satuan, kesetaraan antar satuan, dan penaksiran pengukuran, (5) menentukan dan menafsirkan data sederhana, (6) memecahkan masalah, melakukan penalaran, dan mengomunikasikan gagasan secara matematika. Dalam hal ini, peserta didik diharapkan menjadi lebih aktif untuk belajar dan diberi keleluasaaan mengembangkan ide-idenya untuk menumbuhkembangkan kreativitas dan kemampuan memecahkan masalah dalam kehidupan seharihari.

Kemampuan berpikir kreatif penting dalam memecahkan masalah matematika. Akan tetapi dalam pembelajaran, aspek kreativitas sering ditinggalkan karena lebih menekankan pada penguasaan materi. Sempitnya waktu dan beban materi merupakan alasan utama para guru untuk meninggalkan kreativitas (Budiharti \& Jailani, 2014, p.29). Pengembangan aktivitas berpikir kreatif pada pembelajaran matematika berdasarkan observasi peserta didik kelas IV SD Negeri 1 Prapaglor Pituruh Purworejo tergolong masih rendah. Data ini diambil ketika peserta didik mengerjakan soal yang diberikan guru tanpa diberi tindakan apapun. Berdasarkan hasil pekerjaan tersebut, 13 anak $(81,25 \%)$ mengerjakan seluruh soal dengan satu cara atau jawaban saja, padahal pada petunjuk soal sudah dijelaskan untuk mengerjakan menggunakan berbagai cara. Jawaban peserta didik singkat tanpa diperinci dan dijelaskan. Hasil pekerjaan peserta didik hanya terpacu pada contoh soal 


\section{Jurnal Prima Edukasia, 5 (1), January 2017 - 93}

Resna Maulia Ayu Bernadi

dan rumus yang ada dibuku tanpa mampu memberikan alternatif penyelesaian dengan cara yang berbeda sehingga ketika ada permasalahan lain diberikan, peserta didik mengalami kesulitan untuk mencari penyelesaiannya.

Peserta didik hanya bekerja secara prosedural dan menghafal rumus matematika tanpa menggunakan penalaran. Hal ini mengakibatkan suasana belajar menjadi pasif. salah satu indikator rendahnya kualitas pendidikan kita adalah siswa kurang mampu menyelesaikan permasalahan kontekstual yang dihadapinya. Hal ini disebakan karena proses pembelajaran mentitikberatkan pada penghafalan materi dan prosedur tanpa pernah sekalipun dihadapkan pada kenyataan dilapangan (Handika \& Wangid, 2013, p.86). Proses berpikir kreatif jarang dilatihkan oleh guru dibuktikan dengan guru hanya memberikan soal-soal yang ada di buku. Soal-soal yang dimuat pada buku pelajaran sebagian besar hanya meliputi tugastugas yang harus mencari satu jawaban yang benar, sedangkan kemampuan berpikir yang memungkinkan berbagai kemungkinan jawaban atas suatu masalah jarang sekali muncul. Hal ini dipertegas oleh Sanjaya (2008, p.226) bahwa "salah satu kelemahan proses pembelajaran yang dilaksanakan para guru kita adalah kurang adanya usaha pengembangan kemampuan berpikir siswa. Setiap proses pembelajaran pada mata pelajaran apa pun kita lebih banyak mendorong agar siswa dapat menguasai sejumlah materi pelajaran".

Kemampuan berpikir peserta didik sering terabaikan karena guru cenderung memfokuskan pada pengembangan berpikir analisis saja, padahal perkembangan berpikir kreatif sangat penting karena perkembangan berpikir kreatif peserta didik merupakan perubahan yang sangat mendasar dalam proses pembelajaran. Salah satu hal yang mampu membuat peserta didik mampu meningkatkan kreativitas dalam muatan pelajaran matematika adalah guru hendaknya mampu memilih dan menerapkan pendekatan pembelajaran yang lebih tepat dalam proses belajar mengajar disesuaikan dengan materi yang diajarkan.

Kemampuan berpikir kreatif seseorang menunjukkan kreativitas orang tersebut. Sesuai dengan pernyataan Downing (1997, p.4) "creativity us the process of producing a new whole out of existing elements by arranging them into a new configuration". Kreativitas adalah proses produksi baru seluruh elemen yang ada dengan menyusunnya dalam sebuah konfigurasi baru. Kreativitas setiap orang berbeda-beda, tetapi bukan berarti tidak memiliki kreativitas. Sesuai dengan pendapat tersebut, Downing (1997, p.18) menyatakan "for the vast majority of people, creativity is not lacking; it is merely blocked or hidden by socialization processes over the years". Bagi sebagian besar orang, kreativitas tidak kurang, melainkan hanya diblokir atau disembunyikan oleh proses sosialisasi selama bertahun-tahun. Proses berpikir merupakan sebuah pengalaman memproses persoalan untuk mendapatkan dan menentukan suatu gagasan.

Di antara beberapa pendekatan yang mampu mengembangkan kemampuan berpikir kreatif peserta didik dalam memecahkan masalah pada pembelajaran matematika adalah dengan pendekatan open-ended. Penerapan pendekatan open-ended dalam pembelajaran matematika mempunyai tujuan tertentu. Munandar (1985, p.83) menyatakan bahwa "pertanyaan yang merangsang pemikiran kreatif adalah pertanyaan yang divergen atau terbuka". Soal yang divergen atau terbuka meningkatkan kemampuan berpikir kreatif matematika peserta didik karena peserta didik diberikan kebebasan mengkomunikasikan ide-ide mereka masingmasing berdasarkan hasil pemikirannya tanpa merasa terkekang atau terbebani untuk memecahkan masalah hanya dengan satu cara.

Penelitian ini bertujuan untuk meningkatkan kreativitas peserta didik kelas IV SD Negeri 1 Prapaglor Purworejo melalui pendekatan open-ended. Ada beberapa hal yang dapat diambil manfaat dari penelitian ini, yaitu bagi peserta didik, guru, dan sekolah. Manfaat dari peserta didik yaitu meningkatkan kreativitas peserta didik dan memberi pengalaman nyata dalam pembelajaran, sehingga peserta didik diharapkan mampu mengaplikasikan kemampuan dan pengetahuan yang diperolehnya dalam kehidupan sehari-hari. Bagi guru adalah membantu guru mengatasi permasalahan pembelajaran di kelas, membantu guru dalam meningkatkan kemampuan kreativitas peserta didik, dan menambah wawasan guru di bidang pendidikan khususnya dalam penerapan pendekatan open-ended pada muatan pelajaran matematika dalam pembelajaran tematik integratif. Bagi sekolah adalah meningkatkan kualitas dan prestasi belajar matematika peserta didik di sekolah dan memberi sumbangan pemikiran dalam rangka mencapai tujuan pendidikan nasional. 


\section{Jurnal Prima Edukasia, 5 (1), January 2017 - 94}

Resna Maulia Ayu Bernadi

\section{Metode}

Jenis penelitian yang digunakan adalah Penelitian Tindakan Kelas (PTK) dengan desain PTK model Kemmis \& McTaggart. Tahap dalam setiap siklus terdiri atas empat kegiatan dalam tiga tahap yang terdiri atas perencanaan (plan), tindakan dan pengamatan (act and observe), dan refleksi (reflect). Dari hasil refleksi disusun sebuah modifikasi yang diaktualisasikan dalam siklus berikutnya. Visualisasi desain PTK model Kemmis \& McTaggart disajikan dalam Gambar 1.

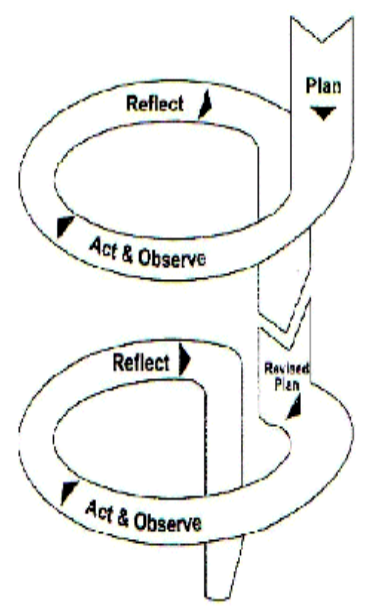

Gambar 1. Siklus PTK model Kemmis \& McTaggart (Arikunto, 2006, p.93)

Keterangan:

Plan: merencanakan tindakan

Act and observe: melakukan dan mengamati tindakan

Reflect: mengevaluasi tindakan

Penelitian ini dilakukan pada bulan Februari 2015 sampai dengan Maret 2015. Penelitian ini dilakukan di SD Negeri I Prapaglor, Pituruh, Purworejo. Subjek penelitian adalah siswa kelas IV SD Negeri I Prapaglor pada Tahun Pelajaran 2014/2015. Siswa kelas IV berjumlah 16 siswa terdiri atas 10 laki-laki dan 6 perempuan.

Penelitian ini terdiri atas 3 siklus. Setiap siklus terdiri atas 3 kali pertemuan. Dalam setiap pembelajaran terdapat perencanaan penyusunan pembelajaran, pelaksanaan tindakan sesuai RPP, observasi sebagai upaya pencermatan terhadap pelaksanaan tindakan, refleksi sebagai bahan acuan merancang perbaikan pada tindakan berikutnya.

Teknik yang digunakan untuk pengumpulan data yaitu observasi dengan instrumen berupa checklist pelaksanaan pembelajaran melalui pendekatan open ended dan tes melalui tes kreativitas.

Kriteria keberhasilan untuk peningkatan kreativitas peserta didik apabila: lebih dari atau sama dengan $75 \%$ peserta didik telah mencapai kriteria kreatif atau sangat kreatif dan terjadi peningkatan hasil tes kreativitas dari siklus I ke siklus II dan siklus II ke siklus III.

Analisis data yang digunakan dalam PTK diarahkan untuk mencari dan menemukan upaya yang dilakukan guru untuk meningkatkan kualitas dan hasil belajar peserta didik. Dengan demikian analisis data dalam PTK bisa dilakukan dengan analisis data kualitatif dan analisis kuantitatif. Analisis data kualitatif digunakan untuk menentukan peningkatan proses belajar khususnya berbagai tindakan yang dilakukan guru, sedangkan analisis data kuantitatif digunakan untuk menentukan peningkatan hasil tes kreativitas sebagai pengaruh dari setiap tindakan yang dilakukan guru.

\section{Hasil dan Pembahasan}

Penelitian ini dilaksanakan mengikuti langkah-langkah atau alur penelitian tindakan kelas yaitu perencanaan (planning), tindakan (acting) dan pengamatan (observing), dan refleksi (reflecting).

\section{Siklus I}

Pelaksanaan tindakan siklus I terbagi menjadi tiga kali pertemuan. Pertemuan pertama dan kedua adalah penyampaian materi dilanjutkan pertemuan ketiga pelaksanaan tes evaluasi. Pertemuan pertama dilaksanakan hari Selasa 3 Februari 2015, pertemuan kedua hari Rabu 4 Februari 2015, dan pertemuan ketiga hari Kamis 5 Februari 2015.

Hasil observasi keterlaksanaan pembelajaran oleh guru pada siklus I yaitu (1) guru sudah menyampaikan tujuan pembelajaran serta menjelaskan pembelajaran mengunakan pendekatan open ended. Guru memberikan apersepsi pada awal pembelajaran, tetapi kurang mendapatkan perhatian dari peserta didik, (2) guru memberikan informasi tentang materi dan petunjuk pembelajaran yang dilakukan yaitu pembelajaran menggunakan pendekatan open ended. Guru juga telah memberikan petujuk kepada peserta didik tentang pengerjaan LKS yaitu dengan cara didiskusikan oleh masingmasing kelompok, (3) guru telah memantau kegiatan yang dilakukan oleh peserta didik, (4) guru selalu memberikan kesempatan kepada anggota kelompok lain untuk memberikan pen- 


\section{Jurnal Prima Edukasia, 5 (1), January 2017 - 95}

Resna Maulia Ayu Bernadi

dapat, tanggapan, ataupun pertanyaan kepada kelompok yang maju, (5) berdasarkan hasil analisis observasi, diperoleh presentase pelaksanaan pembelajaran menggunakan pendekatan open ended pertemuan I sebesar $75 \%$ (cukup) dan pertemuan II sebesar $83 \%$ (baik). Hal ini menjadi catatan agar dipertemuan selanjutnya menjadi lebih baik.

Hasil observasi keterlaksanaan pembelajaran peserta didik yaitu (1) pembagian kelompok diskusi mengalami kendala karena beberapa peserta didik merasa kurang cocok dengan teman kelompoknya, (2) diskusi kelompok belum efektif karena kurang terjadi interaksi antar peserta didik dan beberapa peserta didik tidak mengerjakan soal yang diberikan melainkan ramai dengan temannya, (3) peserta didik belum bisa mandiri mengerjakan soal yang ditugaskan kepada mereka. Mereka sering bertanya kepada guru mengenai cara mengerjakan soal meskipun guru sudah meminta mereka untuk membaca dan memahaminya terlebih dahulu. Hasil penilaian kreativitas peserta didik yaitu dapat dilihat pada Gambar 2.

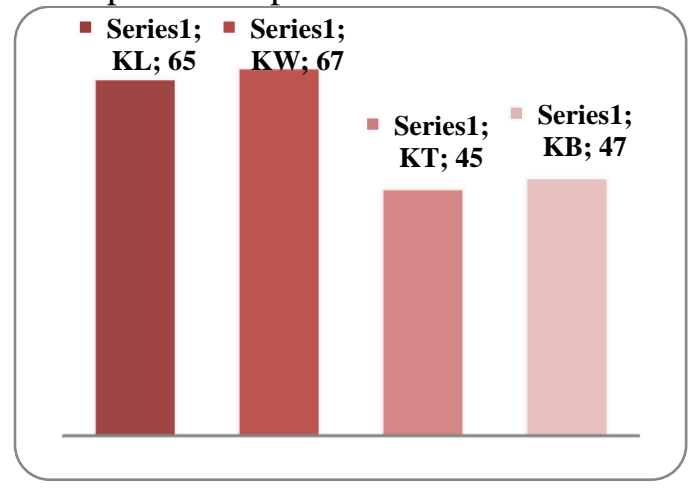

Gambar 2. Grafik Hasil Tes Kreativitas Tiap Aspek Siklus I

Hasil tes kreativitas siklus I, kemudian diolah berdasarkan penentuan kategori kreativitas. Hasil pengkategorisasian hasil tes kreativitas siklus I dapat dilihat pada Tabel 1.

Tabel 1. Distribusi Tes Kreativitas Siklus I

\begin{tabular}{lcl}
\hline Kategori & Frek. & Frek. Relatif (\%) \\
\hline Sangat Kreatif & 0 & $0 \%$ \\
Kreatif & 0 & $0 \%$ \\
Cukup Kreatif & 1 & $6,25 \%$ \\
Kurang Kreatif & 4 & $25 \%$ \\
Sangat Kurang Kreatif & 11 & $68,75 \%$ \\
Jumlah & 16 & $100 \%$ \\
\hline
\end{tabular}

Hasil tes kreativitas siklus I berdasarkan

Tabel 1, belum ada peserta didik yang mencapai kriteria keberhasilan penelitian ini. Kriteria keberhasilan yaitu lebih dari atau sama dengan
$75 \%$ peserta didik telah mencapai kriteria kreatif atau sangat kreatif dan terjadi peningkatan hasil tes kreativitas. Berdasarkan hasil tersebut, penelitian dilanjutkan ke siklus berikutnya

\section{Siklus II}

Siklus kedua dilaksanakan dalam tiga kali pertemuan dengan rincian pertemuan keempat dan kelima penyampaian materi kemudian pertemuan keenam pelaksaan tes evaluasi. Pertemuan keempat dilaksanakan pada hari Sabtu 7 Februari 2015, pertemuan kelima hari Selasa, 24 Februari 2014, dan pertemuan keenam hari Rabu, 25 Februari 2015. Siklus II dilakukan untuk memperbaiki segala sesuatu yang belum tuntas atau tercapai pada siklus I.

Hasil observasi selama siklus II menunjukkan bahwa apabila dibandingkan dengan hasil observasi siklus I pembelajaran menggunakan pendekatan open ended lebih baik dan dapat dikatakan mengalami pengingkatan. Berikut ringkasan hasil observasi kreativitas peserta didik maupun guru dalam pembelajaran pada siklus II.

Hasil observasi kegiatan pembelajaran oleh guru yaitu (1) guru tidak lupa menyampaikan tujuan pembelajaran. Guru menulis tujuan pembelajaran di papan tulis kemudian menjelaskan dengan kalimat-kalimat yang mudah dipahami anak. Dengan menyampaikan tujuan pembelajaran, peserta didik lebih konsentrasi dan terarah dalam menerima pembelajaran. Peserta didik selalu diberi dorongan dan motivasi oleh guru supaya semangat belajar dan percaya diri, (2) guru memberikan informasi dengan memberikan apersepsi untuk mengingat kembali materi yang telah dipelajari sebelumnya. Petunjuk atau informasi tentang permasalahan yang dipelajari selalu diberikan oleh guru, hal ini dilakukan supaya peserta didik tdak lagi kebingungan, (3) guru mempersilahkan masing-masing perwakilan kelompok untuk mempresentasikan hasil diskusinya di depan kelas. Selanjutnya guru memberikan kesempatan kepada peserta didik untuk bertanya dan menyampaikan pendapat baik secara individu maupun kelompok, (4) guru memberikan penghargaan kepada beberapa peserta didik yang berani mengemukakan pendapat atau pertanyaan. Penghargaan yang diberikan berupa sanjungan dan tepuk tangan, (5) guru membahas hasil diskusi dengan memberikan penjelasan dan penguatan materi pembelajaran yang dianggap masih kurang, (6) berdasarkan hasil 


\section{Jurnal Prima Edukasia, 5 (1), January 2017 - 96}

Resna Maulia Ayu Bernadi

analisis observasi, diperoleh presentase pelaksanaan pembelajaran menggunakan pendekatan open ended pertemuan keempat sebesar $83 \%$ (baik) dan pertemuan kelima sebesar 92\% (sangat baik). Terjadi kenaikan 5\% dari pertemuan keempat ke pertemuan kelima Pelaksanaan pembelajaran siklus II juga lebih baik dibandingkan siklus I.

Hasil observasi kegiatan pembelajaran peserta didik siklus II yaitu (1) peserta didik terlihat antusias mengerjakan masalah yang diberikan guru, (2) diskusi berjalan cukup lancar karena hampir seluruh anggota kelompok mengerjakan LKS yang diberikan, (3) jumlah peserta didik yang bertanya tentang langkahlangkah mengerjakan soal sudah berkurang.

Penilaian hasil kreativitas peserta didik siklus II peserta didik kelas IV dapat dilihat pada Gambar 3.

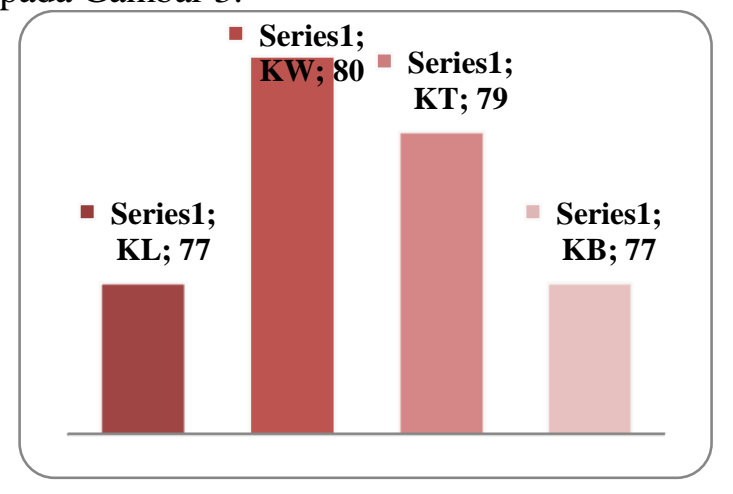

Gambar 3. Grafik Hasil Tes Kreativitas Tiap Aspek Siklus II

Berdasarkan Gambar 3, hasil tes berdasarkan aspek kreativitas dari yang tertinggi adalah keluwesan $80(62,5 \%)$, keterincian 79 $(61,72 \%)$, kemudian kelancaran dan kebaruan memperoleh nilai yang sama yaitu $77(60,16 \%)$. Berdasarkan tabel penentuan kategori kreativitas maka data hasil tes kreativitas siklus II dapat di kategorikan dengan kriteria sangat kreatif, kreatif, cukup kreatif, kurang kreatif dan sangat kurang kreatif seperti Tabel 2.

Tabel 2. Distribusi Hasil Tes Kreativitas Siklus II

\begin{tabular}{|c|c|c|}
\hline Kategori & Frek. & Frek. Relatif (\%) \\
\hline Sangat Kreatif & 0 & $0 \%$ \\
\hline Kreatif & 5 & $31,25 \%$ \\
\hline Cukup Kreatif & 4 & $25 \%$ \\
\hline Kurang Kreatif & 7 & $43,75 \%$ \\
\hline Sangat Kurang Kreatif & 11 & $0 \%$ \\
\hline Jumlah & 16 & $100 \%$ \\
\hline
\end{tabular}

capai kriteria kreatif atau sangat kreatif. Persentase peserta didik yang mencapai kriteria kreatif atau sangat kreatif $31,25 \%$. Kriteria keberhasilan yang kedua apabila terjadi peningkatan dari siklus I ke siklus II. Terjadi atau tidaknya peningkatan dapat dilihat melalui Gambar 4.

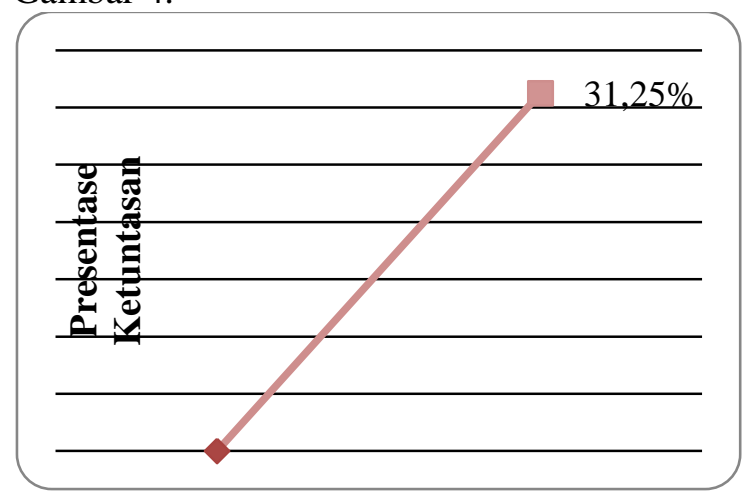

Gambar 4. Peningkatan Kreativitas dari Siklus I ke Siklus II

Dilihat dari Gambar 4, terjadi peningkatan dari siklus I menuju siklus II sebesar $31,25 \%$. Indikator keberhasilan yang kedua terpenuhi yaitu terjadinya peningkatan hasil tes kreativitas dari siklus I ke siklus II. Akan tetapi apabila dilihat dari ketuntasan hasil tes kreativitas, hanya 5 anak $(31,25 \%)$ peserta didik yang mencapai kriteria keberhasilan. Hasil tersebut belum memenuhi kriteria keberhasilan yaitu lebih dari atau sama dengan $75 \%$ peserta didik telah mencapai kriteria kreatif dan sangat kreatif. Oleh karena itu, diperlukan tindakan selanjutnya untuk memperbaiki kekurangankekurangan pada siklus II.

\section{Siklus III}

Siklus III dilakukan sebagai upaya untuk mengatasi permasalahan dalam pembelajaran yang ditemukan dalam siklus II. Siklus ketiga dikatakan berhasil apabila lebih dari atau sama dengan $75 \%$ peserta didik telah mencapai kriteria kreatif atau sangat kreatif dan terjadi peningkatan hasil tes kreativitas dari siklus II. Berdasarkan refleksi dari siklus II, maka direncanakan tindakan kelas pada siklus III yang memasukan upaya revisi dengan cara: (1) guru senantiasa mengingatkan peserta didik yang masih belum aktif berdiskusi, (2) guru lebih jelas dan secara perlahan menerangkan materi dan petunjuk pengerjaan soal agar peserta didik mudah untuk mengikuti, (3) memberikan motivasi, kebebasan, dan kesempatan peserta didik untuk mengemukakan pendapat, gagasan, ataupun argumen, dan (4) 
Jurnal Prima Edukasia, 5 (1), January 2017 - 97

Resna Maulia Ayu Bernadi

memberikan penekanan dan pemantapan pada materi yang dianggap sulit bagi peserta didik.

Siklus III dilaksanakan tiga kali pertemuan. pertemuan ketujuh dan kedelapan digunakan untuk pemberian materi kemudian pertemuan kesepuluh untuk pelaksanaan tes evaluasi. Berikut adalah rincian materi pelajaran pada siklus III. Selama pelaksanaan pembelajaran pada siklus III peneliti bersama observer selalu melakukan observasi, baik kepada guru maupun peserta didik. Berikut hasil observasi pada siklus III.

Hasil observasi kegiatan pemebelajaran oleh guru siklus III yaitu (1) guru tidak lupa menyampaikan tujuan pembelajaran. Maksud dari menyampaikan tujuan pembelajaran adalah agar peserta didik lebih konsentrasi dan terarah dalam menerima pembelajaran. Supaya peserta didik semangat dan percaya diri dalam belajar, guru memberikan dorongan dan memotivasi peserta didik dalam setiap pembelajaran, (2) guru memberikan informasi dengan apersepsi untuk mengingat kembali materi yang telah dipelajari sebelumnya. Petunjuk atau informasi tentang permasalahan yang dipelajari selalu diberikan oleh guru, (3) guru membimbing peserta didik ketika melakukan diskusi kelompok dengan berkeliling kelas, (4) guru memersilahkan perwakilan kelompok untuk mempresentasikan hasil diskusi kelompoknya ke depan kelas. Setiap kelompok hanya diwakili oleh satu anak. Selanjutnya guru memersilakan kepada kelompok lain untuk menyampaikan pendapat, (5) guru membahas hasil diskusi dengan memberikan penjelasan dan penguatan materi pembelajaran yang dianggap masih kurang. Pengambilan kesimpulan dibimbing guru sebelum mencakup semua materi pembelajaran, dan (6) berdasarkan hasil analisis observasi, diperoleh presentase pelaksanaan pembelajaran menggunakan pendekatan open ended pertemuan ketujuh sebesar $100 \%$ (sangat baik) dan pertemuan kedelapan sebesar 100\% (sangat baik). Pelaksanaan pembelajaran siklus III juga lebih baik dibandingkan siklus I dan II.

Hasil observasi kegiatan pemebelajaran peserta didik siklus III yaitu (1) diskusi kelompok sudah berjalan lancar dan lebih baik dibandingkan siklus sebelumnya, dan (2) kemandirian peserta didik mengerjakan tugas semakin meningkat dibuktikan dengan berkurangnya intensitas peserta didik bertanya ketika mengerjakan tugas.

Penilaian hasil kreativitas peserta didik siklus III berdasarkan tiap aspek-aspeknya dapat dilihat pada Gambar 5.

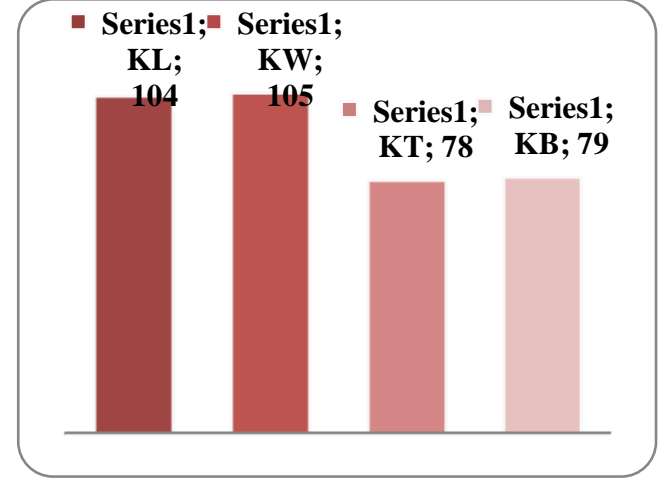

\section{Gambar 5. Grafik Hasil Tes Kreativitas Tiap Aspek Siklus III}

Berdasarkan grafik pada Gambar 5, hasil tes kreativitas tiap aspek dari yang tertinggi adalah keluwesan 105 (82,03\%), kelancaran $104(81,25 \%)$, kebaruan $79(61,72 \%)$, dan keterincian $78(60,94 \%)$. Hasil tes kreativitas kemudian dikategorisasikan berdasarkan kriteria penentuan kategori kreativitas. Hasil pengolahan tes kreativitas siklus III dapat dilihat pada Tabel 3.

Tabel 3. Distribusi Hasil Tes Kreativitas Siklus III

\begin{tabular}{lll}
\hline Kategori & Frek. & Frek. Relatif (\%) \\
\hline Sangat Kreatif & 1 & $6,25 \%$ \\
Kreatif & 11 & $68,75 \%$ \\
Cukup Kreatif & 3 & $18,75 \%$ \\
Kurang Kreatif & 1 & $6,25 \%$ \\
Sangat Kurang Kreatif & 0 & $0 \%$ \\
Jumlah & 16 & $100 \%$ \\
\hline
\end{tabular}

Berdasarkan Tabel 3, hasil kreativitas siklus III telah memenuhi kriteria keberhasilan penelitian yang pertama yaitu lebih dari $75 \%$ peserta didik telah mencapai kriteria kreatif atau sangat kreatif. Kriteria keberhasilan yang kedua apabila terjadi peningkatan dari siklus II ke siklus III. Terjadi atau tidaknya peningkatan dijelaskan melalui Gambar 6.

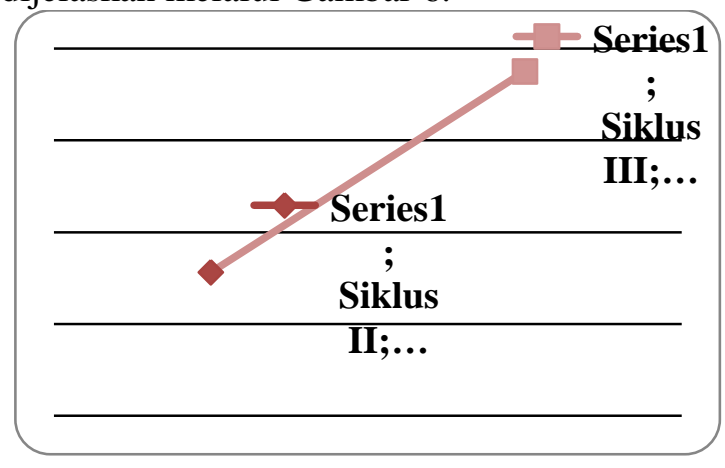

Gambar 6. Peningkatan Kreativitas dari Siklus II ke Siklus III 


\section{Jurnal Prima Edukasia, 5 (1), January 2017 - 98}

Resna Maulia Ayu Bernadi

Berdasarkan Gambar 6, terlihat peningkatan hasil tes kreativitas dari siklus II ke siklus III. Peningkatan hasil tes kreativitas dari siklus II ke siklus III telah memenuhi indikator keberhasilan penelitian yang kedua. Hasil tes kreativitas peserta didik siklus III telah memenuhi semua indikator keberhasilan penelitian ini. Oleh karena itu, penelitian ini tidak dilanjutkan lagi.

Pembahasan

Pelaksanaan pembelajaran untuk meningkatkan kreativitas melalui pendekatan open ended pada muatan matematika kompetensi bilangan desimal di kelas IV SD Negeri I Prapaglor, Pituruh, Purworejo dilaksanakan melalui 3 siklus tindakan. Setiap siklus tindakan dilaksanakan selama tiga kali pertemuan. Pertemuan pertama dan kedua untuk penyampaian materi pelajaran kemudian pertemuan ketiga untuk pelaksanaan tes evaluasi.

Tindakan pada siklus I, siklus II, dan siklus III guru telah menerapkan pendekatan open ended. Pelaksanaan pembelajarannya guru menggunakan langkah-langkah yang telah disusun dalam RPP. Dari hasil analisis yang dilakukan, pada saat pelaksanaan pembelajaran siklus I guru masih belum terbiasa dengan pendekatan open ended. Akan tetapi pada siklus II dan siklus III guru telah dapat melaksanakan pembelajaran melalui pendekatan open ended dengan maksimal. Berdasarkan hasil penelitian, terjadi peningkatan hasil tes kreativitas dari siklus I ke siklus II dan dari siklus II ke siklus III. Pada siklus I, peserta didik belum ada yang mencapai indikator keberhasilan $(0 \%)$. Kemudian hasil tes kreatvitas peserta didik siklus II jumlah peserta didik yang mencapai indikator keberhasilan ada 5 anak $(31,25 \%)$. Pada siklus III jumlah peserta didik yang telah mencapai indikator keberhasilan adalah 12 orang (75\%). Peningkatan kreativitas peserta didik dapat dilihat pada Gambar 7.

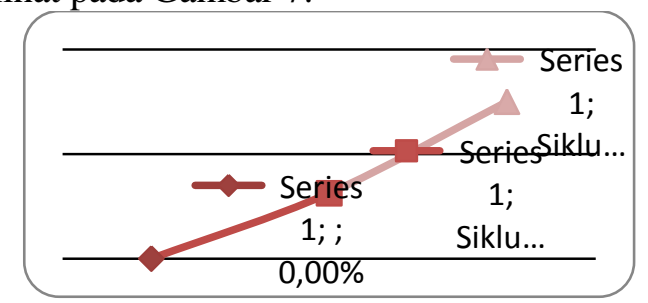

Gambar 7. Peningkatan Hasil Tes Kreativitas

Peningkatan kreativitas salah satu faktornya disebabkan persiapan guru yang optimal dalam melaksanakan langkah-langkah pembelajaran melalui pendekatan open ended. Seperti yang diungkapkan Takahashi (2006, p.2)

the open-ended approach is an instructional approach using an open-ended problem, which has multiple solutions or multiple approaches to a solution. The lesson proceeds by using several students' responses to the given problem to provide experience in finding something new in the process.

Makna dari kalimat tersebut yaitu pendekatan open-ended adalah pendekatan pembelajaran menggunakan masalah terbuka, yang memiliki beberapa solusi atau beberapa pendekatan untuk menyelesaikan suatu masalah. Upaya menemukan strategi ataupun penyelesaian masalah, peserta didik menggunakan kemampuannya untuk menggali informasi sehingga mendorong peserta didik menjadi lebih kompeten dalam memahami ide-ide matematika. Hal demikian tidak terjadi dalam pembelajaran yang menggunakan soal tertutup yang hanya merujuk pada satu jawaban atau strategi penyelesaian. Penggunaan soal tertutup kurang mendorong peserta didik untuk mengeksplorasi berbagai ide-ide matematikanya, sehingga kurang memungkinkannya untuk secara efektif digunakan dalam mengembangkan kemampuan komunikasi matematika sekaligus membangun pemahaman matematika peserta didik. (Mahmudi, 2008, p. 4)

Peran guru dalam peningkatan kreativitas peserta didik sangatlah besar. Guru harus pandai mendesain pembelajaran yang disenangi dan bermakna bagi peserta didik. Konsep yang dipelajari hendaknya dihubungkan dengan dunia anak. Dengan demikian, diharapkan anak lebih mudah memahami konsep-konsep yang dipelajarinya. Guru harus pandai membawa peserta didik mencapai tujuan yang diharapkan. Salah satunya adalah dengan menggunakan pendekatan yang memungkinkan peserta didik berpartisipasi, aktif, dan kreatif terhadap materi yang diajarkan. Salah satu pendekatan yang dapat mencapai tujuan tersebut adalah pendekatan open ended.

Penggunaan soal terbuka juga dapat memicu tumbuhnya kemampuan berpikir kreatif peserta didik. Seperti yang diungkapkan Nohda (2008) "it is possible to have a richer development in their mathematical thinking, and at the same time, foster the creative activities of each student". Soal terbuka memungkinkan peserta didik untuk memiliki perkem- 


\section{Jurnal Prima Edukasia, 5 (1), January 2017 - 99}

Resna Maulia Ayu Bernadi

bangan yang lebih kaya dalam pemikiran matematika mereka, dan pada saat yang sama, mendorong kegiatan kreatif setiap anak.

Kemampuan berpikir peserta didik dalam upaya pemecahan masalah terlihat ketika berusaha menggali informasi sebanyak mungkin, mengumpulkan materi dan menggunakan materi yang diperlukan dalam penyelesaian masalah terbuka. Sehingga dengan adanya proses pembelajaran yang seperti ini mendorong peserta didik untuk berpikir lebih kreatif dalam menyelesaikan masalah. Hal ini senada dengan pendapat Sullivan, et.al (2000, p.6) "it seems that open-ended tasks offer significant possibilities for stimulating the active involvement of students in learning and doing mathematics in classroom situations". Mengandung makna soal terbuka memberikan kemungkinan yang signifikan untuk merangsang keterlibatan peserta didik untuk aktif dalam pembelajaran dan mengerjakan matematika dengan situasi kondusif di kelas.

Proses berpikir kreatif dalam pembelajaran ini terjadi ketika peserta didik diberi latihan soal yang disajikan secara terbuka. Soal yang disajikan dengan terbuka memungkinkan peserta didik memberikan bermacam-macam penafsiran dalam merumuskan permasalahan, serta memungkinkan peserta didik menjawab dengan jawaban yang berbeda-beda. Pembelajaran in juga dapat meningkatkan keterampilan berpikir orisinal, mendorong peserta didik untuk mencari informasi materi yang belum mereka ketahui, serta meningkatkan keterampilan peserta didik dalam mengembangkan materi yang lebih tinggi. Hal ini sesuai dengan ciri kemampuan berpikir kreatif. Kreativitas peserta didik untuk menyelesaikan soal-soal mengalami peningkatan.

Kreativitas tidak hanya terjadi pada bidang tertentu saja, seperti yang diungkakan Pehkonen (1997, p.63) "creativity is not a characteristic only found in artists and scientists, but it is also a part of everyday life". Kreativitas tidak hanya pada seni, sastra, ataupun sains melainkan juga ditemukan pada berbagai bidang kehidupan, termasuk matematika. Pentingnya kreativitas dalam matematika dikemukakan oleh Bishop (Pehkonen, 1997, p.63)

One needs two very different complementary modes of thinking in mathematics: Creative thinking,for which "intuition" is typical, and analytic thinking, forwhich "logic" is typical. Verbality, which is always one dimensional, is connected to logic, and visuality which isusually two- or threedimensional, to intuition.

Seseorang memerlukan dua keterampilan berpikir matematis, yaitu berpikir kreatif yang sering didentikkan dengan intuisi dan kemampuan berpikir analitik yang diidentikkan dengan kemampuan berpikir logis.

Komponen-komponen kreativitas menurut Munandar (Susanto, 2013, p.113) meliputi kelancaran (fluency), keluwesan (flexibility), orisinal (originality), dan keterincian (elaboration). Sebagaimana yang dikemukakan Munandar, bahwa pemikiran kreatif menuntut kelancaran, keluwesan, dan kemandirian dalam berpikir serta mengembangkan suatu gagasan (elaborasi), maka dapat mengajukan pertanyaan-pertanyaan yang baik termasuk pula dalam berpikir kreatif.

Hasil dari komponen kelancaran seimbang dengan keluwesan kemudian keterincian seimbang dengan kebaruan. Komponan kelancaran dimaksudkan dengan keterampilan mencetuskan banyak gagasan, jawaban, penyelesaian masalah atau pertanyaan. Adapun yang dimaksud dengan keluwesan yaitu keterampilan berpikir yang menghasilkan gagasan, jawaban atau pertanyaan yang bervariasi, dapat melihat suatu masalah dari sudut pandang yang berbeda, dan mencari alternatif dalam memecahkan masalah. Kemampuan memerini adalah keterampilan memperkaya dan mengembangkan suatu gagasan sehingga lebih menarik. Keterampilan berpikir kebaruan yaitu mampu mengungkapkan hal yang baru dan unik, memikirkan cara yang tidak lazim untuk mengungkapkan diri, dan mampu membuat kondisi yang tidak lazim dari bagian-bagian atau unsurunsur. (Susanto, 2013, pp.113-114)

Pengembangan perencanaan pembelajaran dengan pendekatan open-ended menurut Suherman, et.al, (2003, p.131) harus memperhatikan hal-hal berikut. (1) tuliskan respon siswa yang diharapkan, (2) tujuan dari problem itu diberikan harus jelas, (3) sajikan problem semenarik mungkin, (4) lengkapi prinsip "posing problem" sehingga siswa memahami dengan mudah maksud dari problem itu, dan (5) berikan waktu yang cukup kepada siswa untuk mengeksplorasi problem. Berikut adalah langkah-langkah pembelajaran tematik integratif menggunakan pendekatan open-ended. 


\section{Jurnal Prima Edukasia, 5 (1), January 2017 - 100}

Resna Maulia Ayu Bernadi

\section{Kegiatan Awal}

Pada kegiatan awal, guru membuka kegiatan pembelajaran dengan mengucapkan salam kepada siswa yang dilanjutkan dengan melakukan presensi kehadiran siswa. Selanjutnya guru memberikan beberapa pertanyaan apersepsi untuk mengetahui pengetahuan awal siswa atau untuk mengingatkan siswa mengenai materi yang telah dipelajari sebelumnya. Kegiatan selanjutnya adalah guru menyampaikan tujuan pembelajaran dan informasi mengenai pelaksanaan kegiatan pembelajaran melalui pendekatan pembelajaran open-ended yang terdiri atas lima langkah, yaitu (1) guru memberi masalah, (2) siswa mengekplorasi masalah, (3) guru merekan respon siswa, (4) pembahasan respon siswa (kelas), dan (5) siswa meringkas apa yang telah dipelajari. Guru melanjutkan kegiatan pembelajaran dengan memberikan motivasi belajar dengan memberikan contoh permasalahan yang berkaitan dengan pokok bahasan yang diajarkan dalam kehidupan sehari-hari yang bertujuan agar siswa tertarik untuk mempelajari pokok bahasan yang diajarkan. Pada akhir kegiatan awal guru menyampaikan pembagian kelompok yang telah ditentukan.

\section{Kegiatan Inti}

Pada kegiatan inti diterapkan lima langkah dalam pendekatan pembelajaran OpenEnded yang dijelaskan sebagai berikut. Pertama, Guru memberi masalah. Pada langkah pemberian masalah, peneliti memberi masalah terbuka kepada masing-masing individu yang kemudian masalah tersebut didiskusikan ke dalam kelompok-kelompok kecil. Kedua, Peserta didik mengeksplorasi masalah. Pada langkah eksplorasi masalah yang dilakukan oleh peserta didik, peserta didik dalam masingmasing kelompok mendiskusikan setiap permasalahan yang terdapat dalam LKS. Tugas guru hanya memberikan bantuan atau mengarahkan peserta didik untuk dapat menyelesaikan setiap permasalahan dengan baik. Ketiga, Merekam respon peserta didik. Guru memberikan tanda pada lembar jawaban yang dimiliki oleh guru mengenai respon masing-masing kelompok berkaitan dengan cara pengerjaan, banyak alternatif pengerjaan, jawaban yang diperoleh dan banyak jawaban yang mungkin diperoleh.

Keempat, Pembahasan respon peserta didik. Pembahasan respon siswa dilakukan dalam diskusi kelas yang diikuti oleh semua kelompok dan dipandu oleh guru. Guru mengarahkan semua kelompok untuk aktif dalam jalannya diskusi. Untuk mengawali pembahasan pada suatu permasalahan guru menunjuk salah satu kelompok atau meminta secara sukarela kelompok yang ingin menyampaikan jawaban dari kelompok mereka atau menanyakan jawaban masing-masing kelompok satu per satu. Setelah jawaban dari kelompok pertama disampaikan guru meminta pendapat dari kelompok lain mengenai kebenaran dari jawaban kelompok pertama atau meminta kelompok lain yang memiliki jawaban yang berbeda atau ingin menambahkan jawaban untuk menyampaikan jawabannya. Pada akhir pembahasan setiap permasalahan, guru menekankan jawaban yang benar dan memberikan penjelasan mengenai jawaban yang salah.

Kelima, Meringkas apa yang telah dipelajari. Pada langkah meringkas apa yang telah dipelajari, guru meminta peserta didik untuk meringkas setiap permasalahan selesai dibahas.

\section{Kegiatan Akhir}

Pada akhir kegiatan pembelajaran guru meminta masing-masing kelompok untuk mengumpulkan hasil diskusi kelompok mereka. Selanjutnya peserta didik bersama guru menyimpulkan hal-hal yang telah dipelajari selama kegiatan pembelajaran secara lisan

\section{Simpulan}

Penerapan pendekatan open ended dalam pembelajaran tematik integrated dapat meningkatkan kreativitas peserta didik diawali dengan memberikan masalah terbuka kepada peserta didik. Peserta didik diberikan waktu yang cukup untuk mengeksplorasi masalah tersebut. Waktu mengeksplorasi dibagi menjadi dua sesi, sesi pertama dikerjakan secara individual dan yang kedua dengan diskusi kelompok. Hasil diskusi dipresentasikan di depan kelas, peserta didik dengan pekerjaan yang berbeda diminta untuk menambahkan dilanjutkan membuat rangkuman dari penemuan yang mereka lakukan.

Hasil implementasi pendekatan open ended menunjukkan bahwa setelah diterapkan pendekatan open ended kreativitas peserta didik mengalami peningkatan. Lebih dari atau sama dengan $75 \%$ peserta didik yang mencapai kriteria kreatif atau sangat kreatif sebanyak 12 anak $(75 \%)$. Hasil tes kreativitas peserta didik mengalami peningkatan dari siklus I ke siklus II dan 


\section{Jurnal Prima Edukasia, 5 (1), January 2017 - 101}

Resna Maulia Ayu Bernadi

dari siklus II ke siklus III. Hasil tes kreativitas peserta didik yang mencapai kategori kreatif dan sangat kreatif pada siklus I sebesar 0\%, siklus II 31,25\%, dan siklus III 75\%. Peningkatan dari siklus I ke siklus II sebesar 31,25\% dan peningkatan dari siklus II ke siklus III sebesar $43,75 \%$.

\section{Daftar Pustaka}

Susanto, A. (2013). Teori belajar dan pembelajaran di sekolah dasar. Jakarta: Kencana Prenada Media Grup

Mahmudi, A. (November 2008). Mengembangkan soal terbuka (openended problem) dalam pembelajaran matematika. Makalah disampaikan pada Seminar Nasional Matematika dan Pendidikan Matematika, di Universitas Negeri Yogyakarta

Budiharti, B., \& Jailani, J. (2014). Keefektifan model pembelajaran matematika realistik ditinjau dari prestasi belajar dan kreativitas siswa sekolah dasar. Jurnal Prima Edukasia, 2(1), 27-41. doi:http://dx.doi.org/10.21831/jpe.v2i1.2 642

Downing, J. P. (1997). Creative teaching: Ideas to boost student interest. Libraries Unlimited

Suherman, E. (2003). Strategi pembelajaran matematika kontemporer. Bandung: JICA

Hurlock, E. B. (2000). Perkembangan anak jilid 2. (Terjemahan dr. Med. Meitasari Tjandrasa). Jakarta: Erlangga

Handika, I., \& Wangid, M. (2013). Pengaruh pembelajaran berbasis masalah terhadap penguasaan konsep dan keterampilan proses sains siswa kelas V. Jurnal Prima Edukasia, $\quad$ l(1), 85-93. doi:http://dx.doi.org/10.21831/jpe.v1i1.2 320.

Nohda, N. (2008). A study of "open-approach" method in school mathematics teaching- focusing on mathematical problem solving activities. Diambil pada tanggal 2 Oktober $2014 \quad$ dari http://www.nku.edu/ sheffield/nohda.ht $\mathrm{ml}$

Nurmin, N., \& Kartowagiran, B. (2013). Evaluasi kemampuan guru dalam mengimplementasi pembelajaran tematik di SD Kecamatan Salahutu Kabupaten Maluku Tengah. Jurnal Prima Edukasia, l(2), 184-194. doi:http://dx.doi.org/10.21831/jpe.v1i2.2 635

Pehkonen, E. (1997). The state-of-art in mathematical creativity. Zentralblatt für Didaktik der Mathematik (ZDM)-The International Journal on Mathematics Education. Diambil pada tanggal 2 Oktober $2014 \quad$ dari http://www.emis.de/journals/ZDM/zdm9 73a1.pdf

Sanjaya, W. (2008). Strategi pembelajaran berorientasi standar proses pendidikan. Jakarta: Kencana

Arikunto,S. (2006). Prosedur penelitian suatu pendekatan praktik. Jakarta: Asdi Mahasatya

Sullivan, P., Warren, E., \& White, P. (2000). Students' responses to content specificopen-ended mathematical tasks. Mathematics Education Research Journal Vol. 12/ No.1, 2-17

Takahashi, A. (2008). Communication as process for students to learn mathematical. Diambil tanggal 10 Oktober 2014 dari http://www.criced.tsukuba.ac.jp/math/ape c/apec2008/papers/PDF/14.Akihiko_Tak ahashi_USA.pdf.

Munandar, U. (1985). Mengembangkan bakat dan kreativitas anak sekolah. Jakarta: Grasindo 